\title{
LINGUO-PRAGMATIC PECULIARITIES OF MODERN ENGLISH POLITICAL DISCOURSE ORGANIZATION (A CASE STUDY OF D. TRUMP'S PUBLIC SPEECHES)
}

\author{
M. Polkhovska, PhD in Philology, Associate Professor, \\ iD ORCID: 0000-0002-7971-9469 \\ Zhytomyr Ivan Franko State University, \\ 40, Velyka Berdychivska St., Zhytomyr, 10008, Ukraine \\ E-mail:marinafeb9@ukr.net
}

The article investigates English political discourse and analyzes linguo-pragmatic characteristics of public political speeches, exemplified by USA President D. Trump's speech to the UN General Assembly. The conducted research testifies that strategies and tactics possess high pragmatic potential and serve to fulfil the main political discourse functions - incentive and manipulative. The author determines that the main strategies and tactics used in D. Trump's speeches are selfrepresentation, opponent's activity critics, agitation strategies, which are realized through cooperative tactics, tactics of attack, and tactics of appeal to positive changes.

Key words:political discourse, political speech, communicative tactics and strategies

DOI: 10.21272/ Ftrk.2018.10(1)-09

The political situation in the modern world is characterized by intensification of power races, which encourages linguists to focus their attention on the problems of discourse and power interrelation and on the language role in the struggle for the power on the one hand, as well as on the reflection of political confrontation in the language on the other hand. The success of any political action depends on rhetoric skills of politicians and on the efficiently built political communication. The political discourse has been investigated by foreign and Ukrainian scientists (O. Baranov, R. Bodak, V. Demiankov, M. Zheltukhina, G. Pocheptsov, L. Slavova, A. Chudinov, O. Sheigal), nevertheless communicative and pragmatic peculiarities of Donald Trump's political speeches lack thorough analysis. The object of our research is political discourse. Linguo-pragmatic characteristics of the US President's political speeches constitute the subject of the paper.

The topicality of the research is determined by a crucial role of political discourse in public opinion shaping, as well as in reflection of the main social, political, and cultural characteristics of discourse participants.

The complexity and at the same time the interest in discourse study as a whole lie in the fact that there is currently no clear and universally accepted definition of this concept. Since discourse is the object of investigation of various sciences (philosophy, psychology, political science, linguistics, etc.), its interpretation that would cover all aspects of its existence is absent. Instead, each science offers its own definition.

In Russian linguistics, the most common definition of discourse is its formulation by $\mathrm{N}$. Arutiunova as a speech immersed in life. Discourse is a text (speech event) in combination with extralinguistic - pragmatic, social, cultural, psychological - factors [1]. While analyzing discourse, linguists try to solve problems of the relation between the concepts of discourse and text, discourse and functional style, discourse and dialogue, as well as to provide the main characteristics of different types of discourse.

Researchers of political discourse, which is considered to be an instantiation of an institutional discourse, focus their attention on forms of public communication of politicians whose purpose is to conquer or retain power [2, c. 25]. In scientific literature, the language of politics is defined as a special language system that is intended for political communication, namely to reach consensus, to adopt and substantiate political and social decisions. Political discourse is a collection of all speech acts used in political discussions, as well as public

(C) Polkhovska M., 2018 
political rules that are consecrated by tradition and proven by experience [3, c. 6]. In the broad sense, it is any speech structures, the subject, the addressee or content of which belong to the sphere of politics [4].

The incentive function is considered to be the main function of political discourse because its goal is not to describe a particular situation, but to persuade, to urge the addressee to act [4; $5 ; 6]$. It is in accordance with this goal that we can determine the effectiveness of political discourse. Among other functional manifestations of political discourse are the function of social control, the legitimization of power, the consolidation of power, the formation of a political picture, social solidarity, social differentiation, agitation and actional functions [4, c.36].

The functional intensity of political discourse determines its content and its formal components. On the one hand, in order to be accessible to the general public, political discourse is standardized, it takes into account the basic rules of vocabulary selection and follows the rules of logical construction and cohesiveness. On the other hand, expressiveness can explicate the emotional state of the speaker, his relation to the subject of the message. The more elaborate the political discourse is, the more successful the speaker uses stylistic figures and reception, the greater is the impact on the audience [2, c. 29].

According to O. Sheigal we distinguish three main groups of political discourse genres: 1) ritual genres (e.g. inaugural speech); 2) orientation genres (e.g., party programs); 3) agitation genres (political speeches) [4].

In the framework of this research, we are primarily interested in the genre of political speech, which we define as a prepared statement with positive or negative assessments, justifications, concrete facts, outlined plans, perspectives of political change. Most researchers believe that political speech refers to the official style of speech and is characterized by accuracy, clarity, conciseness; sequence of presentation; standardized vocabulary; sociopolitical terminology; fixed speech patterns; verbs of induction, imperative mood; impersonal and infinitive structures, etc. [7, c. 390]. Simultaneously, combining signs of other styles, a political speech has such features as the availability of language (often aimed at the general public); a combination of logical, factual, accurate features with emotionality and imagery.

The political speech analysis is carried out from three positions: 1) philological, investigating its syntax and / or semantics; 2) psycholinguistic, measuring the effectiveness of achieving implicit or explicit goals; 3) individually-hermeneutical, revealing the personal meanings of the author or interpreter of discourse under certain circumstances [5]. The language of politics is constantly in the focus of linguistic research and is in bilateral relations with extralinguistic reality. The political situation, values, traditions and priorities of a society are reflected in the language of politics, whereas the choice of linguistic means, in its turn, affects the consciousness of the addressee, the creation of an image of a politician, and the adoption of important decisions [2, c. 31]. Thus, the problem of merging of structural, semantic and pragmatic aspects of the political speech is of a particular interest when we speak of a complex study of the political discourse organization.

In the middle of the previous century, with the development of the speech acts theory, the linguistic and pragmatic approaches to linguistic facts analysis, which was originally associated with the singularization of speech acts, became widespread, and was further developed in the theories of indirect speech acts, communicative intention, communicative strategies and tactics [8, c. 147-148].

Applying the method of speech acts analysis to the study of D. Trump's public speech at the General Assembly of the United Nations, we have identified the following pragmatic types of sentences:

- speech act of statement, the communicative-intentional content of which is elaborated through the affirmation of a certain fact of objective reality, and which corresponds in the political discourse to the transmission of important information about political events, political trends, everything that seems important to the communicative situation, for example:

(1) The stock market is at an all-time high, a record. Unemployment is at its lowest level in 16 years, and because of our regulatory and other reforms, we have more people working in the United States today than ever before. Companies are moving back, creating 
job growth, the likes of which our country has not seen in a very long time, and it has just been announced that we will be spending almost $\$ 700$ billion on our military and defense [9]

In (1), D. Trump, addressing the Assembly representatives in September 2017 at the beginning of his speech provides a brief description of the state of affairs in the United States, stating facts of economic stability.

speech act of promise, the specific feature of its communicative-intentional content is its functional limitation to the future forms of the verb, for example

(2) As long as I hold this office, I will defend America's interests above all else, but in fulfilling our obligations to our nations, we also realize that it's in everyone's interests to seek the future where all nations can be sovereign, prosperous, and secure [9].

In (2), the President of the United States is the guarantor of certain actions (to protect the interests of America above all). Interestingly, Donald Trump promises something that always limits the scope of his promise to a certain condition, such as: his presidency (2), or the need to protect the state or its allies (3),

(3) The United States has great strength and patience, but if it is forced to defend itself or its allies, we will have no choice but to totally destroy North Korea [9].

- directive speech act, whose illocutionary force differs from the advice, that leaves the addressee the freedom to choose whether to follow an instruction or not, to an unambiguous order that is uncontroversial to fulfillment [10]. The content of the directive speech act is the will of the speaker, it contains a direct appeal to action, for example :

(4) If we desire to lift up our citizens, if we aspire to the approval of history, then we must fulfill our sovereign duties to the people we faithfully represent. We must protect our nations, their interests and their futures. We must reject threats to sovereignty from the Ukraine to the South China Sea. We must uphold respect for law, respect for borders, and respect for culture, and the peaceful engagement these allow [9].

Incenting to action in (4), the sign of its mandatory implementation is enhanced by the usage of the modal verb must.

Since the incentive function is the main function of political discourse, keeping in mind that incenting can be explicit and implicit we also find indirect speech acts in D. Trump's speech. We observe cases of pragmatic transposition of a certain communicative type of a sentence as a locutionary act that has a certain illocutionary force whose type is determined due to the communicative intention expressed by certain language means. That is, the locutionary and illocutionary acts in the course of speech implementation do not coincide [11, c. 132]. D. Trump's speech demonstrates the following types of pragmatic transposition, such as: speech act of statement - indirect directive speech act :

(5) It is time for North Korea to realize that the denuclearization is its only acceptable future. [...] It is time for all nations to work together to isolate the Kim regime until it ceases its hostile behavior. [...] It is time for the entire world to join us in demanding that Iran's government end its pursuit of death and destruction [9].

In (5), the pragmatic type of the speech act of statement is replaced by an indirect directive with the following meaning : North Korea should realize ... or all nations should isolate ..., the whole world should join in demanding that the Iranian government. In (6), a complex sentence with a subordinate clause of condition explicates a complex speech act, condition speech act of statement, however the latter is transposed into an indirect warning. The speech act of warning, according to the classifications of speech acts, refers to suggestive speech acts and is an indirect incentive to an action. Its proposition indicates the possible adverse or dangerous consequences, for example,

(6) If the righteous many do not confront the wicked few, then evil will triumph [9].

When using the speech act of question (quesitive), the speaker tries to fill the gap in knowledge, waiting for the recipient's response. The direct speech act of question is not inherent to the public speeches of D. Trump, since there is no direct dialogue with the audience in this case. However, the US President widely uses rhetorical questions that do not 
require a direct answer from the addressee, but only provoke him for the further reflection, for example,

(7) That realism forces us to confront the question facing every leader and nation in this room, it is a question we cannot escape or avoid. We will slide down the path of complacency, numb to the challenges, threats, and even wars that we face, or do we have enough strength and pride to confront those dangers today so that our citizens can enjoy peace and prosperity tomorrow?[9]

It should also be noted that illocution analysis is only one of the levels of speech acts analysis, along with investigation of locution (language means) and perlocution (perlocutionary effect). Since one of the main functions of political discourse is to influence the audience, to manipulate the consciousness, it is the perlocutionary level of the speech act that is to be considered dominant. If the speaker aims to encourage the audience to reach certain conclusions, he/she purposefully brings the audience to this, if the speaker appeals to the mind of the addressee, he/she gives convincing facts and evidence. The suggestive nature of political speeches, which affects not the rational, but the emotional beginning, focuses on the axiological orientation of the addressee. In this case, politicians use expressive means and images (allusions, citations, puns, precedent phenomena, etc.) that are socially marked, focusing on the mass consciousness of the audience. Thus, D. Trump describing the socialist regime in Venezuela, the lack of political and economic freedoms in this country, reminds of the devastating effects of socialism and communism on the Soviet Union, for example,

(8) From the Soviet Union to Cuba to Venezuela, wherever true socialism or communism has been adopted, it has delivered anguish and devastation and failure. Those who preach the tenets of these discredited ideologies only contribute to the continued suffering of the people who live under these cruel systems [9].

Any communicative action is at the same time a definite communicative strategy that is reproduced through it. Each strategy, in its turn, is characterized by a set of tactics and techniques. Public speech always contains an imprint of a politician's personality. With the help of the strategy of self-representation, D. Trump demonstrates his authority, high social status and emphasizes on his personal initiative in the performance of certain tasks. $\mathrm{He}$ defines his priorities as the president of the United States to set his country's interests first (9) - (10) and positions himself as a decisive leader who consciously takes responsibility for his actions (11). Thus the usage of the first person singular pronoun is one of the main language means of implementing this strategy, for example,

(9) As president of the United States, I will always put America first [9].

(10) I was elected not to take power, but to give power to the American people where it belongs [9].

(11) Last month I announced a new strategy for victory in the fight against this evil in Afghanistan. I have also totally changed the rules of engagement in our fight against the Taliban and other terrorist groups [9].

Along with a positive self-presentation, to demonstrate engagement with the audience, to achieve psychological unity with it, to demonstrate understanding of common problems, the President uses tactics of cooperation, in which we observe the usage of the first person plural pronoun, for example,

(12) If we desire to lift up our citizens, if we aspire to the approval of history, then we $\underline{\text { must fulfill our sovereign } \underline{\text { duties }} \text { to the people we faithfully represent; ... we must work }}$ together and confront together those who threaten us with chaos, turmoil, and terror [9].

In (12) we observe the use of a pragmatically marked pronoun we, which can actualize an inclusive or exclusive variety of its usage. While explicating the inclusive meaning, D. Trump means we - the US population (13), we - the world population (14), for example,

(13) Companies are moving back, creating job growth, the likes of which our country has not seen in a very long time, and it has just been announced that we will be spending almost $\$ 700$ billion on our military and defense [9]. 
(14) We live in a time of extraordinary opportunity. Breakthroughs in science, technology, and medicine are curing illnesses and solving problems that prior generations thought impossible to solve. But each day also brings news of growing dangers that threaten everything we cherish and value [9].

Addressing the representatives of the countries at the United Nations General Assembly, D. Trump uses an exclusive variant of the pronoun meaning we - representatives of the world, for example,

(15) To put it simply, we meet at a time of both immense promise and great peril. It is entirely up to us whether we lift the world to new heights or let it fall into a valley of disrepair. We have it in our power, should we so choose, to lift millions from poverty... [9]

Third person plural pronoun they is one of the main means of actualization of criticizing the opponent's activity strategy. It demonstrates the distance from the actions of regimes that neglect the UN values, for example,

(16) The score of our planet today is small regimes that violate every principle that the United Nations is based. They respect neither their own citizens nor the sovereign rights of their countries [9].

The strategy of criticizing the opponent's activity is one of the main strategies used by the President of the United States during his speech at the 72nd Congress of the UN General Assembly. As the leader of one of the most powerful and influential states, D. Trump freely criticizes the political activities of the Democratic People's Republic of Korea, Venezuela and Iran :

(17) No one has shown more contempt for other nations and for the wellbeing of their own people than the depraved regime in North Korea [9].

(18) The Iranian government masks a corrupt dictatorship behind the false guise of a democracy. ... The longest-suffering victims of Iran's leaders are, in fact, its own people [9].

(19) The socialist dictatorship of Nicolas Maduro has inflicted terrible pain and suffering on the good people of that country. This corrupt regime destroyed a prosperous nation by imposing a failed ideology that has produced poverty and misery everywhere it has been tried [9].

To more sharply criticize the opponents, to demonstrate the lack of fears of hostile regimes and his willingness to defend his own ideas, D. Trump resorts to attack tactics, for example,

(20) It is time for North Korea to realize that the denuclearization is its only acceptable future. The United Nations Security Council recently held two unanimous 150 votes adopting hard-hitting resolutions against North Korea [9].

Focusing the audience's attention on the harmful effects of aggressive regimes existence, D. Trump applies the agitation strategy, encouraging the leaders of the states to act. This strategy is actualized in concrete communicative actions, namely: the tactics of calling for positive changes in order to avoid further conflicts between countries and to solve the problems by joint efforts:

(21) But making a better life for our people also requires us to work together in close harmony and unity to create a more safe and peaceful future for all people [9].

(22) Nations of the world must take a greater role in promoting secure and prosperous societies in their own regions [9].

To call for action and to proclaim the correctness and rationality of the decisions, D. Trump also uses the tactics of reference to authoritative leaders. Noting the support of US foreign policy by the leaders of other countries, the President of America focuses attention on a general outlook on the problem around the world, for example,

(23) I want to thank China and Russia for joining the vote to impose sanctions, alongwith all of the other members of the Security Council. Thank you to all involved [9];

(24) and we especially thank Jordan, Turkey and Lebanon for their role in hosting refugees from the Syrian conflict [9]. 
(25) I would like to thank leaders in this room for condemning the regime and providing vital support to the Venezuelan people [9].

To sum up, the study of political discourse cannot be limited to only language means of its implementation. Pragmatic linguistics possesses a great potential for the investigation of hidden communicative motives and intentions. With the help of speech act analysis of D. Trump's public address to the General Assembly of the United Nations, we identified the main communicative types of sentences, namely: speech act of statement - to provide the facts and argumentation of the speaker's point of view; directive speech act, taking into account the fact that one of the main functions of political discourse is incenting to action; promise - to outline positive developments in the future; warning - to explicate a direct threat to aggressive countries. A characteristic feature of the US President's usage of speech tactics and strategies is the domination of strategies of self-presentation, criticism of the opponent's activities, agitation, which are actualized through tactics of cooperation, attack, call for positive change, reference to authoritative leaders.

\section{ЛІНГВОПРАГМАТИЧНІ ОСОБЛИВОСТІ ОРГАНІЗАЩЇ̈ СУЧАСНОГО АНГЛОМОВНОГО ПОЛІТИЧНОГО ДИСКУРСУ (НА МАТЕРІАЛІ ПУБЛІЧНИХ ВИСТУПІВ Д. ТРАМПА)}

М. В. Полховська, канд.філол. наук, доцент

Житомирський державний університет імені Івана Франка, вул. Велика Бердичівська, 40, м. Житомир, 10008, Украӥна E-mail:marinafeb9@ukr.net

У статті розглядається англомовний політичний дискурс $i$ досліджсуються лінгвопрагматичні характеристики політичних промов на прикладі публічного виступу Президента США Дональда Трампа на засіданні Генеральної Асамблеї ООН. Проведений аналіз свідчить про високий прагматичний потенціал використання стратегій і тактик для виконання головних функиій політичного дискурсу - спонукальної $i$ маніпулятивної. Встановлено, щуо основними стратегіями $і$ тактиками у промовах Д. Трампа є стратегія саморепрезентації, стратегія критики діяльності опонента, агітаційна стратегія, які реалізуються через тактику коопераиї, тактику атаки, тактику заклику до позитивних змін.

Ключові слова: політичний дискурс, політична промова, комунікативні тактики та cmpameziï.

\section{ЛИНГВОПРАГМАТИЧЕСКИЕ ОСОБЕННОСТИ ОРГАНИЗАЦИИ СОВРЕМЕННОГО АНГЛОЯЗЫЧНОГО ПОЛИТИЧЕСКОГО ДИСКУРСА (НА МАТЕРИАЛЕ ПУБЛИЧНЫХ ВЫСТУПЛЕНИЙ Д. ТРАМПА)}

М. В. Полховская, канд.філол.наук,доцент

Житомирский государственный університет имени Ивана Франка, ул. Большая Бердичевская, 40, г. Житомир, 10008, Украина

В статье рассматривается англоязычный политический дискурс и исследуются лингвопрагматические характеристики политических речей на примере публичного выступления Президента США Дональда Трампа на Генеральной Асамблее ООН. Проведенный анализ свидетельствует о высоком прагматическом потенциале использования стратегий и тактик для выполнения главных функиий политического дискурса побудительной и манипулятивной. Установлено, что основными стратегиями и тактиками 6 речах Д. Трампа есть стратегия саморепрезентачии, стратегия критики деятельности оппонента, агитационная стратегия, которые реализуются через тактику кооперации, тактику атаки, тактику призыва к позитивным изменениям.

Ключевые слова: политический дискурс, политическая речь, коммуникативные тактики и стратегии.

\section{REFERENCES}

1. Arutiunova, N. D. (1990) Discourse. In V. N. Yartseva (Ed.). Lingvisticheskii ehntsiklopedicheskii slovar'. Retrieved from http://tapemark.narod.ru/les/136g.html 
2. Chanturidze, Yu. M. (2015). Afroamerikanskii politicheskii diskurs: kognitivnyi, lingvokul'torolicheskii $i$ ritoricheskii aspekty [Afro-American Political Discourse : Cognitive, Linguocultural and Rhetorical Aspects]. Unpublished candidate dissertation. Moscow, Russia.

3. Baranov, A. N. \& Kazakevich, Ye. G. (1991). Parlamentskie debaty: traditsii i novatsii [Parliamentary Debates: Traditions and Innovations]. Moscow, Russia: Znanie.

4. Sheigal, Ye. I. (2004). Semiotika politicheskogo diskursa [Semiotics of Political Discourse]. Moscow, Russia: ITDGK "Gnozis".

5. Demiankov, V. Z. (2002). Politicheskii diskurs kak predmet politologicheskoi filologii [Political Discourse as the Subject of Political Philology]. Politicheskaia nauka. Politicheskii diskurs. Istoriia $i$ sovremennyie issledovaniia,3, 32-43. Moscow, Russia: INION RAN.

6. Slavova, L. L. (2010). Movna osobystist' polityka: kohnityvno-dyskursyvnyi aspekt [The Language Personality of the Politician]. Zhytomyr, Ukraine: Vyd-vo ZHDU im. I. Franka.

7. Solovei, G. S. (2009). Politychna leksika v tekstah politychnyh zayav: perekladatskyi ta perekladoznavchyi aspekty [Political lexis in Political Statements: Translation Aspects]. Naukovyi Visnyk Khersonskogo derzhavnogo universytetu. Seriia Ligvistyka. Kherson, 9, 387-391.Kherson, Ukraine: Vyd-vo KHDU.

8. Kondratenko, N. V. (2015). Lingvopragmatychni aspekty doslidzhennia politychnoi komunikatsii v ukrains'komu movoznavstvi [Linguo-Pragmatic Aspects of Political Communication Investigation in Ukrainian Linguistics]. Visnyk Odes'koho Natsional'noho Universytetu. Seriia Philolohiia, 20, 2 (120), 144149.

9. US President D. Trump's Full Speech to the UN General Assembly. (2017). Retrieved from http://tapemark.narod.ru/les/136g.html

10. Pocheptsov, G. G. (2009). Izbrannyie trudy po lingvistike [Selected Works in Linguistics]. Kharkiv, Ukraine: KHNU.

11. Polkhovska, M. V. (2009). Ekzistentsyini rechennia v rannionovoanhliis'kii movi: strukturno-semantychnyi to funktsional'nyi aspekty [Early New English Existential Sentences : Structural, Semantic and Functional Aspects] Unpublished candidate dissertation. Kharkiv, Ukraine.

\section{СПИСОК ВИКОРИСТАНИХ ДЖЕРЕЛ}

1. Арутюнова Н. Д. Дискурс / Н. Д. Арутюнова [Электронный ресурс] // Лингвистический энциклопедический словарь / под ред. В. Н. Ярцевой. - М. : Советская энциклопедия, 1990. - Режим доступа : http://tapemark.narod.ru/les/136g.html

2. Чантуридзе Ю. М. Афроамериканский политический дискурс : когнитивный, лингвокульторолический и риторический аспекты : дис. ... канд. филол. наук : спец. 10.02.04 / Юлия Михайловна Чантуридзе. Москва, 2015. - 187 с.

3. Баранов А. Н. Парламентские дебаты: традиции и новации / А. Н. Баранов, Е. Г. Казакевич. - М. : Знание, 1991. -63 с.

4. Шейгал Е. И. Семиотика политического дискурса / Е. И. Шейгал. - М. : ИТДГК "Гнозис", 2004. $326 \mathrm{c.}$

5. Демьянков В. 3. Политический дискурс как предмет политологической филологии / В. 3. Демьянков // Политическая наука. Политический дискурс: История и современные исследования. - М. : ИНИОН РАН, 2002. - № 3. - С. 32-43.

6. Славова Л. Л. Мовна особистість політика: когнітивно-дискурсивний аспект : монографія / Л. Л. Славова. - Житомир : Вид-во ЖДУ ім. І.Франка, 2010. - 358 с.

7. Соловей Г. С. Політична лексика в текстах політичних заяв: перекладацький та перекладознавчий аспекти / Г. С. Соловей // Науковий вісник Херсонського державного університету. Сер. Лінгвістика. 2009. - Вип. 9. - С. 387-391.

8. Кондратенко Н. В. Лінгвопрагматичні аспекти дослідження політичної комунікації в українському мовознавстві / Н. В. Кондратенко // Вісник ОНУ. Сер. Філологія. - 2015. - Т. 20, Вип. 2(12). - С. 144 149.

9. Промова президента США Д. Трампа на Генеральній Асамблеї ООН - Режим доступу : https://www.vox.com/policy-and-politics/2017/9/19/16333290/trump-full-speech-transcript-un-generalassembly

10. Почепцов Г. Г. Избранние труди по лингвистике : монография / Г. Г. Почепцов. - Харків : ХНУ им. В. Н. Каразина, 2009. - 556 с.

11. Полховська М. В. Екзистенційні речення в ранньоновоанглійській мові: структурно-семантичний та функціональний аспекти : дис. ... канд. філол. наук : спец. 10.02 .04 / Марина Володимирівна Полховська. - Харків, 2009. - 209 с.

Received: 29 Jenuary 2018 